\title{
Pubertal traits of male goats kept on rations supplemented with different protein types
}

\author{
Nasir Salim Elhammali ${ }^{1}$, Adil Salim Elsheikh ${ }^{2}$ \\ ${ }^{1}$ Department of Animal Production, Faculty of Agriculture, Sabah University, Libya. \\ ${ }^{2}$ Community college, Najran University, Saudi Arabia
}

\begin{abstract}
This study was carried out to determine the impact of type of protein supplementation to the ration on pubertal characteristics of male goat kids. Eighteen crossbred (Nubian $\times$ Saanen) weaned male goat kids were distributed to 3 ration groups. Group I $(n=6)$ was kept on a ration supplemented with ground nut cakes, group II $(n=6)$ on a ration supplemented with sesame cakes and group II $(n=6)$ on a ration supplemented with cotton seed cakes. The pubertal traits studied were preputial separation, scrotal circumference at puberty, weight and age at puberty, ejaculate volume, individual motility percent and mass motility of semen, percentages of live and abnormal morphology spermatozoa and the concentration of spermatozoa. The results of this study revealed that only the pubertal body and the percentage of abnormal sperms were significantly influenced $(p<0.05)$ with protein type.The least pubertal body weights and the high percentages of abnormal sperms were recorded in male goats kept on a ration supplemented with cotton seed cakes. Although the scrotal circumference was the least in the group fed on cotton seed cake based ration, it was not significantly $(p>0.05)$ different from that of the other groups. It is concluded that the pubertal traits of male goat kids kept on rations supplemented with groundnut, sesame, or cotton seed cakes are nearly similar. However, cotton seed cakes supplementation to the ration of growing male goat kids reduces the pubertal body weight and increases the percentage of abnormal sperms.
\end{abstract}

Keywords: crossbred; goats; male; puberty; protein type

\section{Introduction}

The balanced nutrition has profound effects on the evolution of the reproductive and puberty traits in all animal species [1]. Contrarily, severe malnutrition has been proved to delay puberty and sexual maturity [2; 2].In case of normal and balanced nutrition puberty takes place when the body weight of an animal reaches approximately50-60\% of the body weight of a mature animal of the species. Adding concentrates with adequate protein level to the ration of animals in cold areas, have been found to accelerate puberty [4]. Attainment of puberty is closely linked to the level of nutrition and body weight [5; 6].On the other hand Elabid [7] stated that the addition of concentrates to the ration of Nubian goats has no effect on the age and weight at puberty. The level of nutrition has direct effect on sexual activity in sheep and goats and faulty nutrition negatively affects the males of many animal species [8]. The male fertility is not affected by the level of protein; however, high protein level in the ration is known to increase the sperm cell concentration and reduces the semen volume and sperm motility [9; 10].Also Coulter and Kozubi [11] found that the quality of semen in animals fed a highenergy diet is lower than those fed on a moderate energy diet, especially the forward motility and sperm head abnormalities. In the Sudan abundant quantities of sesame, ground nut and cotton are available, consequently their byproducts can be used as feed additive. Although, the percentage of protein in sesame and ground nut and cotton cakes are enough to meet the growth requirement in farm animals [12;13], their influences on puberty traits were not investigated. Considering the sparse researches that compares the influences of protein source on male goats pubertal characteristic; the current study is designed to evaluate the effects of adding sesame, ground nut and cotton cakes to the ration on the pubertal traits of crossbred male goats. The pubertal traits investigated were the preputial separation, scrotal circumference, pubertal weight, puberty age, volume of the first ejaculate, individual motility percent of sperms, mass motility of semen, percentages of live and abnormal morphology spermatozoa and the concentration of spermatozoa.

\section{Study area and Animals}

\section{Materials And Methods}

This study was carried out at Hamdan's goat farm in Shambat, Khartoum North, Sudan (Latitude $15^{\circ}$ $36^{\prime} \mathrm{N}$, Longitude $32^{\circ} 32^{\prime} \mathrm{E}$ ). A total of 18 newly born singletons crossbred male goats (Pure Nubian $\times$ Pure Saanen) were used in this study. The kids were born in winter (January 2006). 


\section{Husbandry and management}

The kids were reared with their dams until they were weaned at the age of 12 weeks. Their mean body weight at weaning was $13.31 \pm 0.78 \mathrm{~kg}$. They were then grouped into three treatments groups: group I $(\mathrm{n}=6)$ was fed on a ration made at the farm at a rate of $200 \mathrm{gm}$ per day $(100 \mathrm{gm}$ in the morning and $100 \mathrm{gm}$ in the evenings). This ration is formulated of $19 \%$ groundnut cakes, $45 \%$ sorghum (Sorghum vulgare, vr. Fetarita), $31 \%$ molasses, $3 \%$ mineral mixture and $2 \%$ sodium chloride. Group II $(\mathrm{n}=6)$ were fed the same ration but with $19 \%$ sesame cake instead of the groundnut cakes. Group III $(n=6)$ were fed the same ration but with $19 \%$ cotton cakes instead of the groundnut cakes. The experimental animals were offered water and Alfa alfa ad libitum. They were then injected i.m. with $1 \mathrm{ml} / 50 \mathrm{~kg}$, Ivermectien (Ivomec ${ }^{\circledR}$, Merial, France) to control ectoparasites.

\section{Measuring puberty characteristics:}

The kids were weekly weighed and examined for preputial separation $[14 ; 15 ; 16]$. The scrotal circumferences were measured at puberty with a measuring tape $[15 ; 16]$. Semen collection trials started immediately after preputial separation using artificial vagina $[15 ; 16]$. The semen volume was recorded and the semen was kept in a water bath at $37^{\circ} \mathrm{C}$. The mass motilities and the individual motility percentages were recorded [17]. The percent of live and abnormal sperms were determined with standard method [18]. The sperm cell concentration was determined by counting sperms with a hemocytometer[18; 19]. Onset of puberty was defined as the age when an ejaculate containing motile spermatozoa is collected.

\section{Experimental design}

This experiment is a one factorial design to determine the effect of protein source added to the feed on the characteristics of puberty. The protein sources that were used in this experiment were groundnut, cotton, sesame cakes. Eighteen kids (12weeks old) whose mean body weight was13.31 $\pm 0.78 \mathrm{~kg}$ were distributed to the three groups. The three groups were fed as described above. The pubertal traits investigated were preputial separation, scrotal circumference, weight, puberty age, volume of the first ejaculate, individual motility percent and mass motility of semen, percentages of live and abnormal morphology spermatozoa and the concentration of spermatozoa. Pubertal traits were assed as described above. Onset of puberty was defined as the age when an ejaculate containing motile spermatozoa is collected.

\section{Statistical analysis}

Data are subjected to ANOVA. Data are presented as means \pm standard error of the mean (SE). Probabilities of $\mathrm{p}<0.05$ were considered significant.

\section{Results}

As shown in Table $(1)$, the source of protein significantly $(\mathrm{P}<0.05)$ influenced the puberty body weight of the kids. The average weights at puberty for kids kept on a ration supplemented with groundnut cakes, sesame cakes or cotton seed cakes are $23.4 \pm 1.7,20.3 \pm 9,18.2 \pm 1.1 \mathrm{~kg}$, respectively. The mean body weight was high in the group fed on a ration supplemented with the groundnut cake followed by those fed on a ration supplemented with sesame cake while the least mean body weight was recorded in those kids kept on a ration supplemented with cottonseed cake. The highest weight at puberty recorded for the groundnut cake group was $29.400 \mathrm{~kg}$, sesame cake group was $24,200 \mathrm{~kg}$ and cottonseed cake group was $20.800 \mathrm{~kg}$, while the least weights were $18.200 \mathrm{~kg}, 18.200 \mathrm{~kg}$ and $14 \mathrm{~kg}$, respectively. The other reproductive traits (table 1) were not influenced (p $>0.05$ ) with the source of protein. However, the testicular size (scrotal circumference) is smaller in the group fed on a ration supplemented with the cotton cakes. No significant differences $(p>0.05)$ were observed in the pubertal semen characteristics except the abnormal sperm percent which was significantly high $(p<0.05)$ in male goat kids fed on ration supplemented with sesame or cotton cakes (Table 2).

Table 1. Influence of protein source supplemented to the ration on male goat pubertal traits

\begin{tabular}{llcc}
\hline & \multicolumn{3}{c}{ Protein source } \\
\cline { 2 - 4 } Parameters & \multicolumn{1}{c}{ Groundnut cake } & Sesame cake & Cotton cake \\
\hline Preputial separation (days) & $16.7 \pm 0.4$ & $16.8 \pm 0.3$ & $17.5 \pm 0.3$ \\
Pubertal weight (kg) & $23.4 \pm 1.7^{\mathrm{a}}$ & $20.3 \pm 0.9^{\mathrm{a}, \mathrm{b}}$ & $18.2 \pm 1.1^{\mathrm{b}}$ \\
Pubertal age (weeks) & $30.3 \pm 0.3$ & $27.5 . \pm 0.2$ & $28.7 \pm 1.3$ \\
Scrotal circumference (cm) & $22.2 \pm 0.8$ & $21.5 \pm 1.4$ & $18.8 \pm 1.1$ \\
\hline
\end{tabular}

Data are means \pm SE of six replicates. Values with different superscripts in the same raw differ

$$
\left({ }^{\mathrm{a}, \mathrm{b}} \mathrm{p}<0.05\right) \text {. }
$$


Table 2. Influence of protein source supplemented to the ration on semen characteristics of pubertal male goats

\begin{tabular}{llll}
\hline & \multicolumn{3}{c}{ Protein source } \\
\cline { 2 - 4 } Parameters & Groundnut cake & Sesame cake & Cotton cake \\
\hline Ejaculate volume (ml) & $0.65 \pm 0.3$ & $0.63 \pm 0.8$ & $0.68 \pm 0.1$ \\
Mass motility & $3.67 \pm 0.2$ & $3.83 \pm 0.2$ & $3.67 \pm 0.2$ \\
Individual motility (\%) & $82.5 \pm 3.4$ & $79.2 \pm 2.1$ & $77.5 \pm 2.5$ \\
Live sperm (\%) & $90.0 \pm 1.9$ & $87.2 \pm 1.1$ & $87.2 \pm 2.1$ \\
Sperm cell concentration & $2.2 \pm 0.6 \times 10^{9}$ & $1.9 \pm 0.3 \times 10^{9}$ & $2.4 \pm 0.5 \times 10^{9}$ \\
Abnormality (\%) & $3.8 \pm 0.7^{\mathrm{a}}$ & $6.7 \pm 0.8^{\mathrm{b}}$ & $7.3 \pm 1.1^{\mathrm{b}}$ \\
\hline
\end{tabular}

Data are means \pm SE of six replicates. Values with different superscripts in the same raw $\operatorname{differ}\left({ }^{\mathrm{a}, \mathrm{b}} \mathrm{p}<0.05\right)$.

\section{Discussion}

This study demonstrated that cross-bred male goat kids fed on a ration supplemented with groundnut cakes have pubertal body weights superior to those fed on ration supplement with cotton or sesame cakes. Many studies have shown that the protein found in cotton, groundnut or sesame cakes meets the growth requirements that precede puberty $[12 ; 13 ; 20]$. However the results of this study proved that feeding prepubertal male goat kids on a ration supplemented with cotton seed cakes, reduces their pubertal body weight and the scrotal circumference. This difference is attributed to the difference in the level of protein where cotton seed cake has a lower protein level compared to that of ground nut and sesame [21]. Also the effect of the toxic gosypol of cotton seeds, which were not exposed to high temperatures during oils manufacturing, cannot be ignored. In this study, pubertal weights of male goat kids fed on a ration containing sesame cakes are similar to those fed on a ration containing groundnut cakes and this is due to the similarity in the level of protein [21]. The age of puberty of all kids was similar and not affected by the source of protein added to the ration. This is normal because puberty is attained at a certain age and is highly influenced by the season and breed and the extreme nutritional deficiency is known to affect the age of puberty $(2 ; 3 ; 7 ; 22]$.

The study pointed no significant variations in most of the semen characteristics between all the food groups and all semen properties were good; except the increments in the percentages of abnormal and dead sperms recorded in the group of kids fed on ration supplemented with cotton seed cake. It is well known that male fertility is not affected much by rations and ration that contains only $12 \%$ of the protein or less is sufficient to get a good quality semen, but a severe shortage in the proportion of protein may result in production of poor quality semen $[9 ; 10 ; 11]$ The increment of the percentages of abnormal and dead sperms recorded in the group fed on a ration supplemented with cotton seed cakes can be attributed to the presence of gossypol which was not well exposed to high heat during oil manufacturing.

\section{Conclusion}

It is concluded that the pubertal traits of male goat kids kept on rations supplemented with groundnut cakes, sesame cakes or cotton seed cakes are nearly similar. However, cotton seed cakes supplementation to the ration of male goat kids reduces the pubertal body weight and increases the percentage of abnormal sperms.

\section{References}

[1] S. A. Makawi. Reproductive development in the Butana, the Kenana, the cross-breed and the Friesian bulls bred in the Sudan .Doctoral thesis. Faculty of Veterinary Medicine, University of Khartoum (1994).

[2] B. J. Filipseand J. O. Almquist. Effects of total digestible nutrient intake from birth to year of age on growth and reproductive development and performance of dairy bulls. J. Dairy Sci. 44, 1986, 901-914.

[3] G. H. Arthur, G.H. Noakes, D.E. The male animal in: Veterinary Reproduction and obstetrics. $4^{\text {th }}$ Edition. The English language Book Society (E.L.B.S) and Bailliere Tindall. 2001, 673-778.

[4] J. O. Almqusit,E. E. Grubeand G. L. Rozenberger (1982). Effect of thawing time on fertility of bovine spermatozoa in French straws. J. Dairy Sci., 65, 1982, 824-827.

[5] G. H. Beardenand J. W. Fuquay.Applied Animal Reproduction ( $4^{\text {th }}$ ed) Prentice Hall, Upper Saddle, New Jersey, 1997.

[6] E. S. E. Hafez and B. Hafez. Seminal evaluation in : Reproduction in Farm Animals, $7^{\text {th }}$ ed. ( Lea and Fibiger, Philadelphia, U.S.A,2000) 376-389

[7] K. H. Elabid. Studies on some productive and reproductive traits of Sudan Nubian goats under village and small holder system. Doctoral thesis, University of Khartoum, Sudan, 2002.

[8] A. B. Elwishy, S. A. Elsawaf, M. S. Abdu and A. A. Omar. Influence of iodine supplement to native bulls on seasonal variation in libido and semen characteristics. Animal Production Abstract, 422, 1970, 422, 112-116.

[9] H. Alsaadi. Reproduction andartificial insemination- Part Iand II .College of Veterinary Medicine, University of Baghdad,1989. (In Arabic).

[10] A. Zayed and A. A. Salhab. Physiology of reproduction and artificial insemination (practical part) Omar Mukhtar Agricultural University- Albayda -Libya. 1994. (In Arabic).

[11] G. H. Coulterand G. C. Kozub. Testicular development epididymal sperm reserves and seminal quality in two year old Hereford and Angus bulls: effects of two levels of dietary energy. J. Anim. Sci., 59 (2).1984, 432-440.

[12] R. M. Ali. Basis of feeding poultry and farm animals "Egyptian feedstuffs) Cairo University, 1972.(In Arabic).

[13] P. I. Rekwot. Effects of feeding maize stover and cotton cake on onset of puberty in Punjabi Boss-Indic Heifers. J. of tropical Animal Health and Production, 36, 2006, 637-644. 
[14] F. Q. G. Bezerra, C. R. AguiarFilho, L. M. FreitasNeto, E. R. Santos Junior, R. M. Chaves, E. M. P. Azevedo, M. H. B. Santos, P. F. Lima and M. A. L. Oliveira. Body weight, scrotal circumference and testosterone concentration in young Boer goat males born during the dry or rainy seasons. South African J Anim. Sci, 39, 2009, 301- 306.

[15] A. S. Elsheikh, N.S. Elhammali, M. T. Ibrahim, and A. M. Alqurashi. Influence of season of birth on pubertal characteristics of male goat kids.JASA, 2 (1), 2013, 108-111.

[16] N. S. Elhammali, A. M. Alqurashi, M.T. Ibrahimand A. S. Elsheikh (2013). Puberty of crossbred male goat kids. J Am Sci, 9(4), 2013, 95-99.

[17] G. Evans and W. M. C. Maxwall. Salmon's artificial insemination of Sheep and Goats. $1^{\text {st }}$ edition. Butterworth's, London, United Kingdom, 1987.

[18] E. Blom. Interpretation of spermatic cytology in bulls. Fertility Sterility 1, 1950, 223-238.

[19] B. Leboeuf, B. Restall and S. Salamon. Production and storage of goat semen for artificial insemination. AnimReprodSci26, 2000, 113-141.

[20] O. O. A. Fasanya, E. C. I. Molokwu, L.O. Eduvie, and I. I. Dim I. I. Dietary supplementation in the savannaBrrow goat Gestation and us does. Anim Reprod Sci, 29 (1-2), 1992, 167-174.

[21] R. Y. Sulieman, and R. A. Mabrouk, The nutrient composition of Sudanese animal feeds. Sudan Animal Resources Corporation. Bulletin III. PP. 1999, 1-16.

[22] G, E. Dickerson and D. B. Laster, B. (1975). Breed, heterosis and environmental influences on growth and puberty in ewe lambs. J. Anim. Sci. 41, 1975, 1-9. 